Original scientific paper - Izvorni znanstveni rad

UDK: 637.075

\title{
Expression of toxic shock syndrome toxin-1 gene of Staphylococcus aureus in milk: Proof of concept
}

doi: $10.15567 /$ mljekarstvo.2018.0102

\author{
Milijana Babićn , Marija Pajićn , Aleksandra Nikolićn , Vlado Teodorović ${ }^{1}$, \\ Milorad Mirilović ${ }^{,}$, Lazar Milojević ${ }^{2}$, Branko Velebit ${ }^{2 *}$
}

${ }^{1}$ Faculty of Veterinary Medicine, University of Belgrade, Bul. Oslobođenja 18, 11000 Belgrade, Serbia ${ }^{2}$ Institute of Meat Hygiene and Technology, Kaćanskog 13, 11040 Belgrade, Serbia ${ }^{3}$ Faculty of Agriculture, University of Novi Sad, Trg Dositeja Obradovića 8, 21000 Novi Sad, Serbia

Received - Prispjelo: 06.07.2017. Accepted - Prihvaćeno: 17.12.2017.

\begin{abstract}
The aim of this study was to assess the expression of a toxic shock syndrome toxin-1 (TSST-1) gene of Staphylococcus aureus in different types of milk, depending on inadequate temperature and storage conditions. Pasteurized and UHT milk were inoculated with monotoxic TSST-l strain of S. aureus and growth kinetics was determined by the drop plate method using Baird-Parker agar medium in accordance with EN ISO 6888-1. The patterns of gene regulation were detected by quantitative reverse transcriptase PCR. Relative quantification method for statistical significance testing was used to detect significant gene expression responses. The results of experiments showed the dependence of the growth rate and consequent up-regulation of TSST-1 encoding gene on storage time-temperature and type of milk. In contaminated pasteurized and UHT milk kept at both $15{ }^{\circ} \mathrm{C}$ and $22^{\circ} \mathrm{C} \mathrm{S}$. aureus significantly increased its virulent potential over time. This effect was a bit more emphasized in UHT milk serving as a "proof of concept". Possible explanation could be a presence of lactic acid bacteria in pasteurized milk which is known to have down-regulatory effect on TSST-1 gene. Maintenance of the milk storage temperature below $8{ }^{\circ} \mathrm{C}$ and employment of microbiological control measures in hygienic practices, from milk producer through retailer and on to the consumer is of utmost importance to decrease risk of non-emetic staphylococcal poisoning.
\end{abstract}

Key words: S. aureus, toxic shock syndrome toxin-1, milk

\section{Introduction}

Staphylococcal food poisoning (SFP) is one of the most common foodborne illnesses resulting from ingestion of staphylococcal enterotoxins (SE) produced in food by enterotoxigenic strains of Staphylococcus aureus. Milk is considered to be a good substrate for $S$. aureus growth and enterotoxin production, and contaminated raw milk and dairy product have been often involved in SFP (Asao et al., 2003). Infected dairy animals suffering mastitis may contaminate bulk milk, Furthermore, human handlers, milking equipment, the environment, as well as unhygienic udder and surrounding skin may be other possible sources of bulk milk contamination. From a food safety perspective, that is a concern because enterotoxigenic $S$. aureus may be a risk of SFP after consumption of raw milk products (Jorgensen et al., 2005). SFP is suspected when the symptoms including nausea, violent vomiting, abdominal cramps, and diarrhea affect the patients between 1 and $8 \mathrm{~h}$ after food consumption. To date, over 20 SEs have been characterized and many $S$. aureus strains can synthesize more than one type of toxins (Kerouanton et. al., 2007; Loncarevic

*Corresponding author/Dopisni autor: E-mail: branko.velebit@inmes.rs 
et al., 2004; Tamarapu et al., 2001). These toxins are heat resistant low molecular weight proteins (MW 26.900-29.600), which means that their biological activity remains unchanged even after thermal processing of food (Martin et al., 2004; McKlauchlin et al., 1999). The five classic enterotoxins (SEA, SEB, SEC, SED, and SEE) are known to be responsible for $95 \%$ of staphylococcal food poisoning cases and SEA and SED are most common enterotoxins recovered from food poisoning outbreaks, possibly because they can be produced in a wide range of growth conditions (aw and $\mathrm{pH}$ ).

The remaining $5 \%$ of outbreaks are associated to newly described SE's and TSST-1. It is difficult to obtain accurate estimates of the incidence of $S$. aureus intoxications because most cases are not reported.

Toxic shock syndrome (TSS), a relatively rare condition (0.06 cases per 100,000 people) caused by TSST-1 or more potent exotoxins is characterized by fever, rash, hypotension, constitutional symptoms, multi-organ failure and death (Saha et al., 1996; Thomas et al., 2007). Superantigenic-producing S. aureus incorporated into the digestive tracts might cause enterocolitis (Watanabe et al., 2001) and persist for a long time in the intestinal microbiota of infants (Lindberg et al., 2000). Enteric TSST-1 activates systemic $\mathrm{T}$ cells and leads to a dysregulated, but exuberant immunological activity causing the remission and flare-up cycle of mucosal inflammation in patients with ulcerative colitis (Shiobara et al., 2007). TSST-1 producing strains of S. aureus are widespread in humans, animals and foods and such distribution may play significant role in the epidemiology of TSS, while the data on prevalence in the environment are currently very scarce.

Staphylococcal food poisoning is acquired by ingestion of preformed toxin and has been linked primarily to the SEs (Jablonski and Bohach, 1996). The main symptom - emesis - is often accompanied by nausea and abdominal cramping, but lacks of a fever and shock. It is still unclear why these two superantigenic toxins (SE and TSST-1) show different pathogenesis in infections and food poisoning induced by $S$. aureus. Research study conducted by Li et al. (2011) showed strong resistance of the superantigenic activity of TSST-1 to heat treatment, pepsin and trypsin digestion. Although TSST1 was rapidly degraded to smaller fragments after treatment with pepsin or trypsin, they retained significant superantigenic and lethal shock activities relative to those of SEA. These results indicated that the different resistance of SEA and TSST-1 participates in the different pathogenic activities of superantigenic toxins during food poisoning and TSS.

Although pasteurization kills S. aureus cells, heat-stable SEs and TSST-1 generally retain their biological activity (Evenson et al., 1988; Asao et al., 2003). Thus, because of the importance of these toxins in the public health and food sectors, an efficient screening to detect the prevalence of enterotoxic strains in foods is required. To cast some light on the TSST-1 toxin hazard in milk, we have conducted a research study aiming to develop "proof of concept" by comparing the expression of TSST-1 encoding gene of $S$. aureus in cases when different milk types were properly stored and as well as they suffered time-temperature abuse.

\section{Material and methods}

\section{Growth modelling}

Strain of S. aureus producing TSST-1 was obtained from the American Type Culture Collection (ATCC BAA-2094). Different types of milk that had previously tested negative for $S$. aureus have been inoculated with an average of $2.4 \times 10^{4} \mathrm{CFUmL}^{-1}$ of the above strain. The milk samples tested were pasteurized and UHT $1.6 \%$ fat milk obtained from retail. Inoculated milk model samples were incubated at $8{ }^{\circ} \mathrm{C}$ (calibrator-untreated control sample), $15^{\circ} \mathrm{C}$ and $22^{\circ} \mathrm{C}$ (environmental temperature) to simulate inappropriate transport and storage conditions. Experiments were always conducted in parallel. Two groups of plates in each experiment were inoculated 12 hours apart to cover 24 hours. A 24-hour sampling interval was used for the extraction of TSST-1 encoding gene mRNA. The enumeration of S. aureus was performed at a 24-hour interval and the average values were calculated from the results of the parallel and repeated experiments. During the incubation, $\mathrm{pH}$ of the model samples was measured periodically (data not shown). Enumeration of $S$. aureus was performed using the Baird-Parker drop plate count method in accordance with EN ISO 6888- 1 and the plates were cultured at $37 \pm 1{ }^{\circ} \mathrm{C}$ for $24 \pm 2$ hours and $48 \pm 2$ hours. 


\section{RNA extraction with commercially available kit}

Commercially available kit PureLink RNA Mini Kit (Invitrogen, USA) was used for RNA extraction, including lysis and silica membrane extraction according the manufacturers' instructions and further optimized by using $25 \mathrm{mg} / \mathrm{mL}$ of lysozyme (Sigma, USA) for $60 \mathrm{~min}$ at $37^{\circ} \mathrm{C}$. This optimization resulted in a 2-4 fold increase in total RNA yield (data not shown).

Briefly, bacteria were resuspended in $100 \mu \mathrm{L}$ RNase free water and transferred to a tube containing $0.4 \mathrm{~g}$ of acid-washed 150-212 mm silica beads (Sigma, USA), $400 \mu \mathrm{L}$ Lysis buffer R (provided by the kit) and $400 \mu \mathrm{L} 90 \%$ phenol solution (AppliChem, Germany) vortexed for 20 seconds before using the BeadBeater cell disruptor (Biospec Products, USA) with setting 6.5 for $60 \mathrm{sec}$. The samples were cooled on ice and the beat-beading step repeated twice. Afterwards, samples were centrifuged for 5 min at $16,000 \times \mathrm{g}$ and supernatants are mixed with equal volume of $100 \%$ ethanol (Sigma, USA). The samples (including any remaining precipitate) were transferred to the silica columns and centrifuged for $15 \mathrm{sec}$ at $13,000 \times \mathrm{g}$ at room temperature (RT). Columns where washed with $700 \mu \mathrm{L}$ of Wash buffer and centrifuged for $15 \mathrm{sec}$ at 13,000 $\times \mathrm{g}$ at RT. Second washing stage is $500 \mu \mathrm{L}$ of Wash buffer II with the same centrifugation protocol. Finally, RNA was recovered in $40 \mu \mathrm{L}$ of $\mathrm{RNase}$-free water, incubated for $1 \mathrm{~min}$ and centrifuged for $1 \mathrm{~min}$ at $12,000 \mathrm{x} \mathrm{g}$. All steps were done at room temperature, except where otherwise noticed.

\section{DNase treatment}

Genomic DNA was digested with RQ DNase I (Promega, USA). Briefly, $3 \mu \mathrm{L}$ of DNase I and $3 \mu \mathrm{L}$ of reaction buffer were added to the RNA sample and incubated at $37^{\circ} \mathrm{C}$ for $30 \mathrm{~min}$. DNase I enzyme was inactivated with $5 \mu \mathrm{L}$ of $25 \mathrm{mM}$ EDTA, incubated for $10 \mathrm{~min}$ at $65^{\circ} \mathrm{C}$.

\section{RNA quality determination}

The concentration and purity of the total RNA was spectrometrically determined using a NanoDrop 1000 (Thermo Scientific). Three independent measurements of the same sample were performed. The absorbance ratio A260/A280 was used as an indicator of protein contamination and A260/A230 as an indicator of polysaccharide, phenol, and/or chaotropic salt contamination. The integrity of the total RNA was assessed by visualization of the 23S/16S banding pattern. Electrophoresis was performed on $1.5 \%$ agarose gel at $80 \mathrm{~V}$ for $60 \mathrm{~min}$. The ethidium bromide stained gel was visualized by GelDoc2000 (Bio-Rad, USA). RNA was stored at $-80{ }^{\circ} \mathrm{C}$ for further use.

\section{cDNA synthesis}

cDNA synthesis was performed using commercial Super Script VILO (Invitrogen, USA) kit, according manufacturer's instructions. The same amount of total RNA (500 ng/20 $\mu \mathrm{L}$ ) was reverse transcribed in two reaction volumes: $20 \mu \mathrm{L}$, as described by the manufacturer, and $10 \mu \mathrm{L}$. To determine the possibility of genomic DNA carry-over, control reactions were performed under the same conditions but lacking the reverse transcriptase enzyme (no-RT control). All RNA extracted was absent of significant genomic DNA, as determined by an average cycle threshold difference of $18.5 \pm 3.5$, equivalent to a maximum quantification error of $0.0003 \%$.

\section{Gene expression quantification}

TSST-1 gene expression was determined by qPCR. Oligonucleotide primers for the detection of fts $Z$ (housekeeping gene) and TSST-1 encoding gene (tst) were designed using the Primer3 software having S. aureus ATCC BAA-2094 genome, as template (Table 1).

Table 1. Primers used in gene expression analysis

\begin{tabular}{ccc}
\hline Gene & \multicolumn{1}{c}{ Primer sequence } & Amplicon size \\
\hline \multirow{2}{*}{$f t s Z$} & F: 5'-ATCCAAATCGGTGAAAAATTAACAC-3' & 121 bp \\
& R: 5'-CCATGTCTGCACCTTGGATTG-3' & \\
\hline \multirow{2}{*}{$t s t$} & F: 5'-TCATCAGCTAACTCAAATACATGGATT-3' \\
& R: 5'-TGTGGATCCGTCATTCATTGTT-3' & 88 bp \\
\hline
\end{tabular}


qPCR analysis was performed using Maxima SYBR Green Master Mix (Fermentas, Lithuania). For transcripts detection, $2 \times$ SYBR Green I (Invitrogen, USA) was added to a standard PCR mix. The $20 \mu \mathrm{L}$ reaction volume contained $2 \mu \mathrm{L}$ of diluted cDNA or no-RT control, 10 pmol of each primer, $6 \mu \mathrm{L}$ nuclease free $\mathrm{H}_{2} \mathrm{O}$, and $10 \mu \mathrm{L}$ of the respective $2 \times$ master mix. Primer efficiencies were determined by the dilution method as well as performing a temperature gradient reaction from 50 to $65{ }^{\circ} \mathrm{C}$. At $60{ }^{\circ} \mathrm{C}$, both set of primers had the best and more similar efficiencies values. qPCR run was performed on a MX3005P (Agilent, USA) with the following cycle parameter: $95^{\circ} \mathrm{C}$ for $30 \mathrm{~s}, 40$ cycles of $95^{\circ} \mathrm{C}$ for $10 \mathrm{~s}, 60{ }^{\circ} \mathrm{C}$ for $15 \mathrm{~s}$ and $68^{\circ} \mathrm{C}$ for $15 \mathrm{~s}$. qPCR products were analyzed by melting curves for unspecific products or primer dimer formation. Relative fold increase of specific mRNA transcripts in milk comparing with planktonic cultures, was calculated using $2^{\Delta \mathrm{Ct}}$ method, a variation of the Livak method, where 2 stands for the $100 \%$ reaction efficiency (the reaction efficiency was determined experimentally and thus $100 \%$ efficiency was replaced by the real efficiency) and $\Delta \mathrm{Ct}=\mathrm{Ct}$ (housekeeping gene)-Ct (target gene). The data analysis was based on 3 independent experiments.

\section{Statistical analysis}

One-way analysis of variance (ANOVA) was performed to identify conditions when $t s t$ gene was altered by at least a 2.0-fold increase or decrease in expression between groups. The numbers of significantly up- and down-regulated genes in each comparison group were identified by applying a $\mathrm{P}$ value of $<0.05$, together with fold change cut-offs of 2.0fold decrease and 2.0-fold increase.

\section{Results and discussion}

To the extent of our knowledge, this is the first study to characterize TSST-1 encoding gene expression changes of $S$. aureus grown in the different milk types, stored at inappropriate temperatures during prolonged period, compared to milk contaminated with the $S$. aureus and held at $8{ }^{\circ} \mathrm{C}$. This temperature has been considered as a set off temperature, since deviations from it will result in an increased risk of microbiological hazards.
Over the past decades TSST-1 from $S$. aureus has been considered as the most important cause of TSS in humans. Therefore, the evaluation of the presence of TSST-1 producing S. aureus, as well as $S$. aureus pathogenic activity under different storage conditions assessing the combination of virulence genes is of great importance both in human and in veterinary medicine (Zecconi et al., 2006; Piccinini et al., 2009). Highly contaminated milk with tst-positive strain of $S$. aureus is a source of contamination of dairy products during processing, because staphylococcal toxins are highly heat resistant and survive after the commercially relevant heat treatment process (Le Loir et al., 2003). The main sources of milk contamination with high number of $S$. aureus are: i) animals, when cows contaminate milk during milking via infected udder; ii) unhygienic milking procedures, unsanitary equipment and inadequate storage conditions; iii) humans (handlers contaminate milk via manual contact or via respiratory tract by coughing and sneezing), when contamination occurs after heat treatment of the milk (Le Loir et al., 2003; Chye et al., 2004). Hence, it is highly important to quickly decrease the temperature of raw milk below $8{ }^{\circ} \mathrm{C}$ and to achieve the best storage conditions to keep milk fresh for as long as possible, but no longer than necessary. Also is required to respect the principles of good hygiene practice and good manufacturing practice (Chye et al., 2004).

In general, results from our experiments indicated that the $S$. aureus counts, as well as relative expression of tst gene increased in both pasteurized and UHT milk incubated at different temperatures during storage period.

In pasteurized milk inoculated with the tstpositive strain of $S$. aureus and stored at $15^{\circ} \mathrm{C}$ for 72 hours, an increase of $S$. aureus count from 4.36 to $8.38 \log _{10}$ cfu $\mathrm{mL}^{-1}$ was observed, as shown in Figure 1. During the same period, expression of $t s t$ gene was down-regulated by 0.67 -fold after initial 24 hours of incubation $(\mathrm{P}=0.643)$, but significantly up-regulated within the next 24 hours, reaching 2.85 -fold $(\mathrm{P}=0.012)$ increase after 48 hours of incubation (Figure 2). By the end of the Day 3, gene expression was still significantly up-regulated compared to milk stored at $8{ }^{\circ} \mathrm{C}$, at the level 2.46 -fold of increase $(\mathrm{P}=0.021)$. In inoculated UHT milk stored at $15^{\circ} \mathrm{C}$, similar growth pattern was observed, 
increasing from $4.36 \log _{10} \mathrm{cfu} \mathrm{mL}^{-1}(0$ hours $)$ to $8.48 \log _{10} \mathrm{cfu} \mathrm{mL}^{-1}$ (72 hours). However, there was no downregulation recorded during incubation, but rather an insignificant increase of 1.36fold $(\mathrm{P}=0.178)$ after 24 hours which continuously increased to 2.81-fold after 48 hours $(\mathrm{P}=0.015)$, and reaching plateau value of 2.73 -fold increase after 72 hours $(\mathrm{P}=0.015)$.

As expected, growth pattern of tst-positive strain of $S$. aureus in pasteurized milk stored at $22^{\circ} \mathrm{C}$ dramatically changed compared to pattern recorded at $15{ }^{\circ} \mathrm{C}$ (Figure 3). Namely, no lag phase was observed and growth kinetics increased exponentially reaching $7.55 \log _{10} \mathrm{cfu} \mathrm{mL} \mathrm{mL}^{-1}$ just after 24 hours and reaching plateau of 8.28 and $8.41 \log _{10}$ cfu $\mathrm{mL}^{-1}$ after 48 and 72 hours, respectively. At this storage temperature, tst gene relative expression increased to 1.83 -fold $(\mathrm{P}=0.062)$ after 24 hours (compared to milk stored at $8{ }^{\circ} \mathrm{C}$ ) and reached 3.18-, and 3.36-fold increase in 48 and 72 hours, respectively $(\mathrm{P}=0.002)$. In UHT milk stored at $22{ }^{\circ} \mathrm{C}$, growth was somewhat similar, reaching $7.73 \log _{10} \mathrm{cfu} \mathrm{mL}^{-1}$ just after 24 hours and reaching plateau of 8.32 and $9.00 \log _{10}$ cfu $\mathrm{mL}^{-1}$ after 48 and 72 hours, respectively. tst gene relative expression increased to 2.57 -fold $(\mathrm{P}=0.022)$ after 24 hours (compared to milk stored at $8{ }^{\circ} \mathrm{C}$ ) and reached 2.74-, and 2.93-fold increase in 48 i.e. 72 hours, respectively $(\mathrm{P}=0.014)$ (Figure 4).

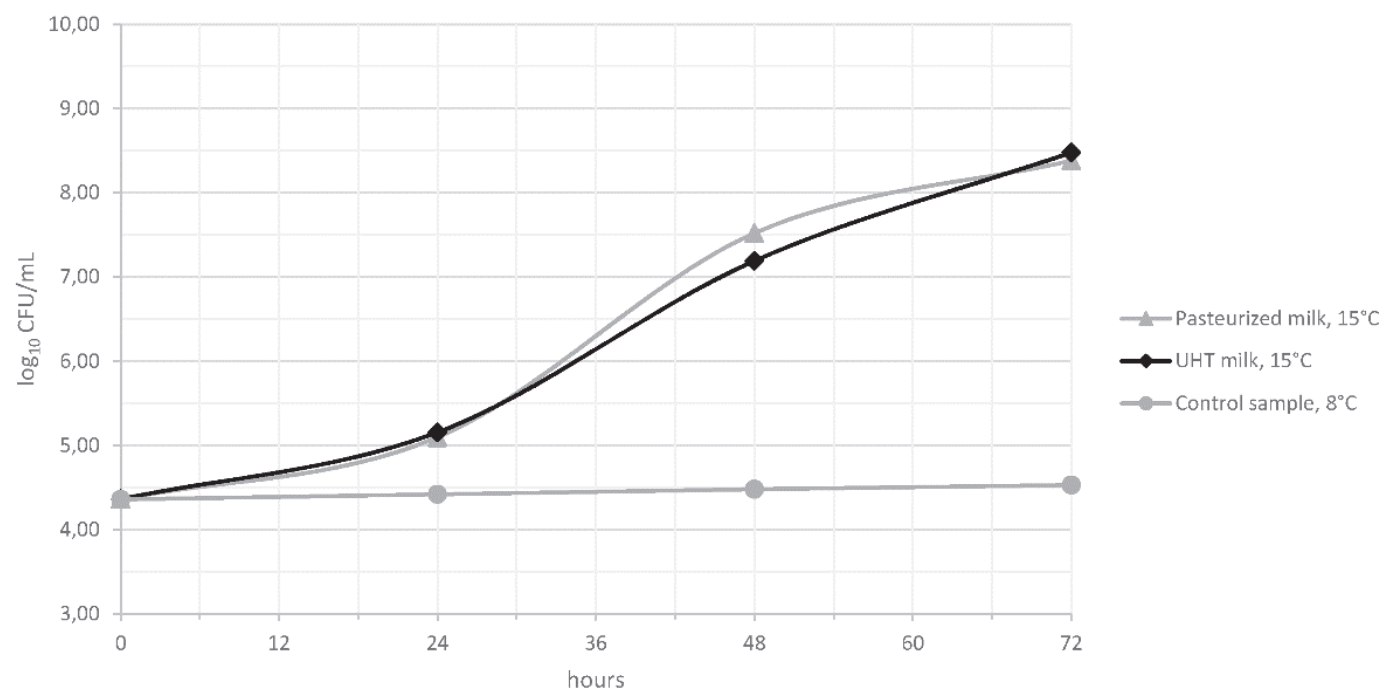

Figure 1. Growth kinetics of TSST1 positive S. aureus at $15^{\circ} \mathrm{C}$

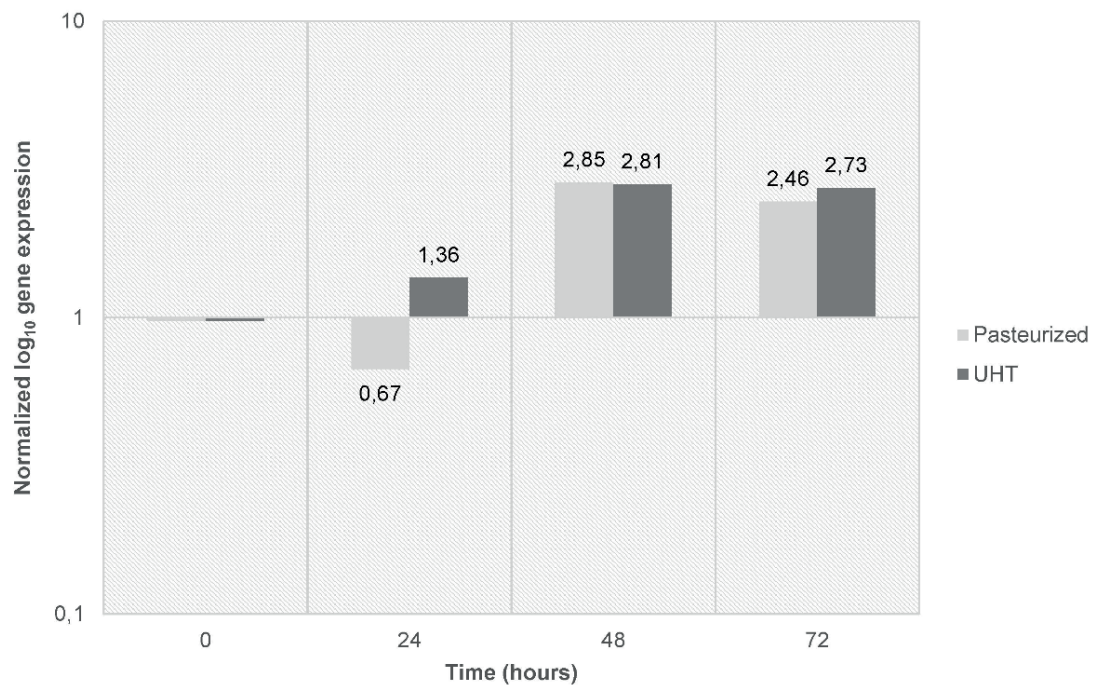

Figure 2. $t$ ts gene expression at $15^{\circ} \mathrm{C}$ 
Due to rather scarce data on potential risk of TSST-1 positive $S$. aureus in milk and dairy products, establishing incidence of this pathogen in milk is of critical importance. A comprehensive research study was conducted in 2015 by Vitale et al., who showed that from a total of 102 isolated S. aureus strains in a screening of 971 various food products, $89.2 \%$ were originated from dairy products, while the subsequent molecular analysis of the toxin genes of 102 isolated S. aureus strains, showed that more than $42 \%$ harbored the $t s t$ gene, whereby about $80 \%$ of the strains that carried the tst gene $(35 / 43)$ were isolated from dairy products. However, some authors reported lower occurrence of TSST-1 S. aure- us in food samples, i.e. $13.5 \%$ of the samples tested in Korea (Oh et al., 2007) and 12\% in Iran (Dallal et al., 2010). Srinivasan et al. (2006) investigated the prevalence of 16 enterotoxin genes (SEA-SEE and SEG-SEQ) and toxic shock syndrome toxin gene (TSST-1) of Staphylococcus aureus isolated from milk of cows with mastitis. From a total of 78 S. aureus examined, TSST-1 gene was detected in $20(25.6 \%)$ isolates and was always found in combination with other enterotoxin genes. They considered that the high prevalence of enterotoxin genes and TSST-1 in S. aureus may be important as it is relevant to udder pathogenicity and food hygiene. In contrast, Arcuri et al. (2010) have examined 291

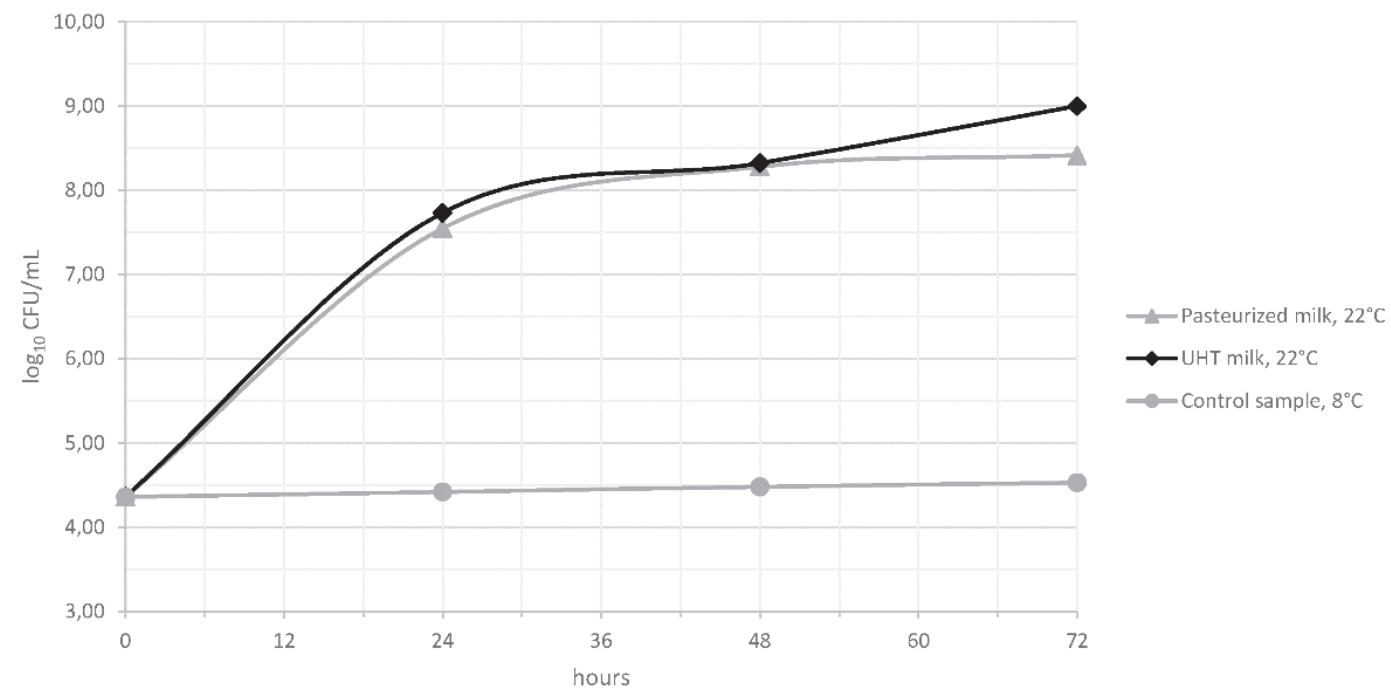

Figure 3. Growth kinetics of TSST1 positive S. aureus at $22^{\circ} \mathrm{C}$

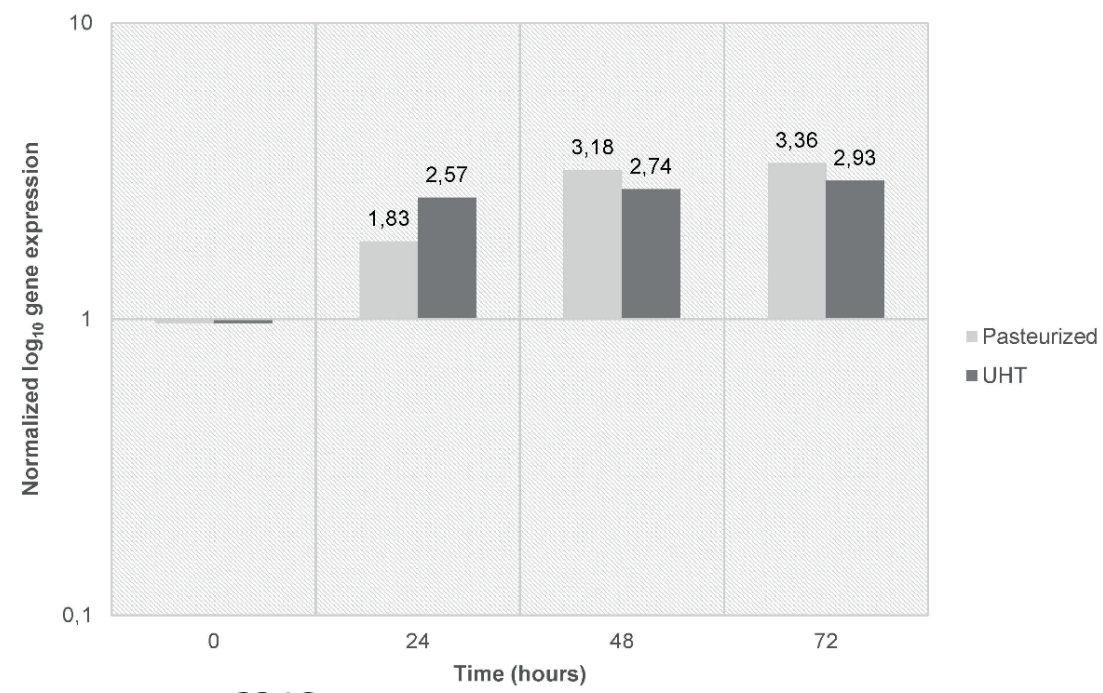

Figure 4. tst gene expression at $22^{\circ} \mathrm{C}$ 
Staphylococcus aureus isolates from mastitic cow's milk, bulk tank milk, and Minas fresh cheese for staphylococcal enterotoxin genes and TSST-1 by PCR assay, and they found the tst-1 gene of $S$. aureus in only eight isolates, but none from mastitic cow's milk.

One of the possible explanations why tst gene was initially down-regulated in pasteurized milk is presence of lactic acid bacteria. Almost all of the staphylococcal super-antigens are encoded on variable genetic DNA elements, with the exception of SE-1 X, which is encoded on the core chromosome. TSST-1 is encoded by genes on S. aureus pathogenicity islands (SaPIs) (McCormick et al., 2001). Like other exo-proteins and cell surface virulence factors, TSST-1 staphylococcal super-antigen is controlled by global regulatory systems designated as accessory gene regulator $(a g r)$. It was not our intent to discuss these $a g r$ regulatory elements in detail. Readers are encouraged to read important reviews that discuss global regulatory pathways in detail (Novick, 2003; Pragman and Schlievert, 2004). However, Nouaille et al (2014) established the ability of Lactococcus lactis, a lactic acid bacterium widely used in the dairy industry, to down-regulate a major staphylococcal virulence regulator, the $a g r$ system, and, as a consequence, $a g r$-controlled toxins. The $a g r$ system relies on at least two general properties of LAB: their ability to decrease both $\mathrm{pH}$ (Cretenet et al., 2011) and redox potential via oxygen-independent mechanisms (Nouaille et al., 2014).

Milk is highly vulnerable to contamination with S. aureus, especially at higher temperature during prolonged storage, so the aim of this study was to determine the expression of TSST-1 encoding gene of $S$. aureus when milk was stored under different temperatures during prolonged time. The incubation of milk at $15^{\circ} \mathrm{C}$ and $22^{\circ} \mathrm{C}$ (room temperature) was used to simulate inappropriate transport and storage conditions. In this study, the number of $S$. aureus in both pasteurized and UHT milk stored at $8{ }^{\circ} \mathrm{C}$ remained unchanged during the entire storage period. In contrast, the increase in storage temperature and storage time of both, pasteurized and UHT milk, resulted in increased number of $S$. aureus, as also observed by Janštová et al. (2012). The number of $S$. aureus of pasteurized and UHT milk cultured at $15{ }^{\circ} \mathrm{C}$ and $22{ }^{\circ} \mathrm{C}$ for $24 \mathrm{~h}$, exceeded the threshold of $10^{5} \mathrm{CFU} \mathrm{mL} \mathrm{mL}^{-1}$, which represents the risk for enterotoxin production (Duquenne et. al., 2010). Also, some authors (Fujikawa and Morozumi, 2006; Medve' ová et al., 2009) reported an increase in the number of $S$. aureus at different incubation temperatures of milk, and consequently the increase in the virulence of the pathogen. $S$. aureus is able to grow in a wide range of temperatures from $7{ }^{\circ} \mathrm{C}$ to $48.5^{\circ} \mathrm{C}$, with the optimum growth being observed at $30{ }^{\circ} \mathrm{C}$ to $37^{\circ} \mathrm{C}$, while the optimal temperature for enterotoxin production is between $10^{\circ} \mathrm{C}$ and $46{ }^{\circ} \mathrm{C}$ (Schmitt et al., 1990). In our study, the highest $S$. aureus counts were recorded for the strain producing TSST-1 toxin when cultured in pasteurized and UHT milk at $22^{\circ} \mathrm{C}$.

\section{Conclusions}

Given that milk is derived from animals, it inherently carries the risk of being contaminated with pathogens from its source (cattle, goats, sheep, and the farm environment). Although TSST-1 is usually not suspected to cause staphylococcal enterotoxicosis, due to lack of classical symptoms such as "projectile vomiting". Results obtained in this "proof of concept" model showed that abuse of storage temperature in combination with prolonged storage time of contaminated milk may significantly increase TSST-1 health hazard. The key factor in the prevention of milk-borne disease is consumer avoidance of raw milk consumption and implementation of good hygiene practices and effective monitoring from production through the delivery chain, retailer and to the consumer, especially maintaining the storage temperature below $8{ }^{\circ} \mathrm{C}$.

\section{Acknowledgments}

Funding for research presented in this paper was provided through projects of Ministry of Education, Science and Technological Development of Republic of Serbia, TR-31034 and III46009. 


\section{Ekspresija gena za toksični šok sindrom toksin 1 Staphylococcus aureus u mlijeku - dokaz koncepta}

\section{Sažetak}

Cilj ovog istraživanja bio je ispitati ekspresiju gena za sintezu toksina 1 toksičnog šok sindroma (TSST-1) Staphylococcus aureus u različitim vrstama mlijeka držanim u neadekvatnim temperaturnim uvjetima. Pasterizirano i UHT mlijeko inokulirano je monotoksičnim TSST-1 pozitivnim sojem $S$. aureus i držano pri $15^{\circ} \mathrm{C}$ i $22^{\circ} \mathrm{C}$ tijekom 72 sata. Kinetika rasta određena je drop plate metodom korištenjem Baird-Parker agara sukladno EN ISO 6888-1. Regulacija gena za TSST-1 određena je lančanom reakcijom polimerazom uz reverznu transkripciju u realnom vremenu. Za određivanje promjena u ekspresiji gena, korištena je metoda relativne kvantifikacije. Rezultati ispitivanja pokazali su da su stopa rasta $S$. aureus kao i posljedična regulacija gena za sintezu TSST-1 ovisni o intenzitetu temperature, a djelomično i o vrsti mlijeka. Povećana regulacija ovog gena utvrđena je pri obje temperature, ali stopa porasta virulentnog potencijala bila je znatnije izražena u UHT mlijeku držanom pri $22{ }^{\circ} \mathrm{C}$ koje je služilo kao model u dokazu koncepta. Jedan od mogućih razloga za niži virulentni potencijal u pasteriziranom mlijeku bilo je prisustvo bakterija mlječne kiseline za koje se zna da imaju represivni utjecaj na ekspresiju gena za sintezu TSST-1. Održavanje temperature čuvanja mlijeka ispod $8{ }^{\circ} \mathrm{C}$ i primjena kontrolnih mikrobioloških mjera u higijeni mlijeka od proizvođača, preko maloprodaje do krajnjeg potrošača, od kritičnog je značaja za smanjenje rizika nastanka stafilokoknih trovanja bez pojave povraćanja.

$$
\begin{aligned}
& \text { Ključne riječi: } \text { S. aureus, toksin } 1 \text { toksičnog šok } \\
& \text { sindroma, mlijeko }
\end{aligned}
$$

\section{References}

1. Arcuri, E.F., Angelo, F.F., Guimarães, M.F., Talon, R., Borges, M.de F, Leroy, S., Loiseau, G., Lange, C.C., Andrade, N.J., Montet, D. (2010): Toxigenic status of Staphylococcus aureus isolated from bovine raw milk and Minas frescal cheese in Brazil. Journal of Food Protection 73 (12), 2225-2231. https://doi.org/10.4315/0362-028X-73.12.2225
2. Asao, T., Kumeda, Y., Kawai, T., Shibata, T., Oda, H., Haruki, K., Nakazawa, H., Kozyki, S. (2003): An extensive outbreak of staphylococcal food poisoning due to low-fat milk in Japan: estimation of enterotoxin $\mathrm{A}$ in the incriminated milk and powdered skim milk. Epidemiology and Infection 130 (1), 33-40. https://doi.org/10.1017/S0950268802007951

3. Chye, F.Y., Abdullah, A., Ayob, M.K. (2004): Bacteriological quality and safety of raw milk in Malaysia. Food Microbiology 21 (5), 535-541. https://doi.org/10.1016/j.fm.2003.11.007

4. Cretenet, M., Nouaille, S., Thouin, J., Rault, L., Stenz, L., François, P., Hennekinne, J.A., Piot, M., Maillard, M.B., Fauquant, J., Loubière, P., Le Loir, Y., Even, S. (2011): Staphylococcus aureus virulence and metabolism are dramatically affected by Lactococcus lactis in cheese matrix. Environmental Microbiology Reports 3, 340-351. https://doi.org/10.1111/j.1758-2229.2010.00230.x

5. Dallal, M.M.S., Salehipour, Z., Eshraghi, S., Mehrabadi, J.F., Bakhtiari, R. (2010): Occurrence and molecular characterization of Staphylococcus aureus strains isolated from meat and dairy products by PCR-RFLP. Annals of Microbiology 60, 189-196. https://doi.org/10.1007/s13213-010-0025-4

6. Duquenne, M., Fleurot, I., Aigle, M., Darrigo, C., Boreze'e-Durant, E., Derzelle, S., Bouix, M., Deperrois-Lafarge, V., Delacroix-Buchet, A. (2010): Tool for quantification of staphylococcal enterotoxin gene expression in cheese. Applied and Environmental Microbiology 76 (5), $1367-1374$. https://doi.org/10.1128/AEM.01736-09

7. Evenson, M. L., Hinds, M. W., Bernstein, R. S., Bergdoll, M. S. (1988): Estimation of human dose of staphylococcal enterotoxin A from a large outbreak of staphylococcal food poisoning involving chocolate milk. International Journal of Food Microbiology 7 (4), 311-316. https://doi.org/10.1016/0168-1605(88)90057-8

8. Fujikawa, H., Morozumi, S. (2006): Modeling Staphylococcus aureus growth and enterotoxin production in milk. Food Microbiology 23 (3), 260-267. https://doi.org/10.1016/j.fm.2005.04.005

9. International Organization for Standardization. (1999). Microbiology of food and animal feeding stuffs - Horizontal method for the enumeration of coagulase-positive staphylococci (Staphylococcus aureus and other species) - Part 1: Technique using Baird-Parker agar medium (ISO Standard No. 6888-1).

10. Jablonski, L.M., Bohach, G.A. (1996): Staphylococcus aureus. in Fundamentals of food microbiology. eds Beuchat M., Doyle M., Montville T. ASM Press, Washington, D.C., 353-375.

11. Janštová, B. Jr., Necidová, L., Janštová, B., Vorlová, L. (2012): Staphylococcus aureus growth and enterotoxin production in different types of milk. Acta Universitatis Agriculturae et Silviculturae Mendelianae Brunensis LX (5), 103-108.

12. Jorgensen, H.J., Mork, T., Caugant, D.A., Kearns, A., Rorvik, L.M. (2005): Genetic variation among Staphylococcus aureus strains from Norwegian bulk milk. Applied and Environmental Microbiology 71(12), 8352-8361. https://doi.org/10.1128/AEM.71.12.8352-8361.2005 
13. Kerouanton, A., Hennekinne, J.A., Letertre, C., Petit L., Chesneau, O., Brisabois, A., De Buyser, M.L. (2007): Characterization of Staphylococcus aureus strains associated with food poisoning outbreaks in France. International Journal of Food Microbiology 115, 369-375. https://doi.org/10.1016/j.ijfoodmicro.2006.10.050

14. Le Loir, Y., Baron, F., Gautier, M. (2003): Staphylococcus aureus and food poisoning. Genetics and Molecular Research 2 (1), 63-76.

15. Li, S.-J., Hu, D.-L., Maina, E.K., Shinagawa, K., Omoe, K. and Nakane, A. (2011): Superantigenic activity of toxic shock syndrome toxin- 1 is resistant to heating and digestive enzymes. Journal of Applied Microbiology 110, 729-736. https://doi.org/10.1111/j.1365-2672.2010.04927.x

16. Lindberg, E., Nowrouzian, F., Adlerberth, I., Wold, A.E. (2000): Long-time persistence of superantigen-producing Staphylococcus aureus strains in the intestinal microbiota of healthy infants. Pediatric Research 48, 741-747. https://doi.org/10.1203/00006450-200012000-00007

17. Loncarevic, S., Jorgensen, H.J., Lovseth, A., Mathisen, T., Rorvik, L.M. (2004): Diversity of Staphylococcus aureus enterotoxin types within single samples of raw milk and raw milk products. Journal of Applied Microbiology 98, 344-350. https://doi.org/10.1111/j.1365-2672.2004.02467.x

18. Martin, M.C., Fueyo, J.M., Gonzales-Hevia, J.M., Mendoza, M.C. (2004): Genetic procedure for identification of enterotoxigenic strains of Staphylococcus aureus from three food poisoning outbreaks. International Journal of Food Microbiology 94, 279-286. https://doi.org/10.1016/j.ijfoodmicro.2004.01.011

19. McCormick, J.K., Yarwood, J.M., Schlievert, P.M. (2001). Toxic shock syndrome and bacterial superantigens: an update. Annual Review of Microbiology 55, 77-104. https://doi.org/10.1146/annurev.micro.55.1.77

20. McKlauchlin, J., Narayann, G.L., Mithani, V., Oneill, G. (1999): The detection of enterotoxin and toxic shock syndrome toxin genes in $S$. aureus by PCR. Journal of Food Protection 63, 479-488. https://doi.org/10.4315/0362-028X-63.4.479

21. Medve'ová, A., Valík, L., Sirotná, Z., Liptáková, D. (2009): Growth characterisation of Staphylococcus aureus in milk: a quantitative approach. Czech Journal of Food Sciences 27 (6), 443-453.

22. Nouaille, S., Rault, L., Jeanson, S., Loubière, P., Le Loir, Y., Even, S. (2014). Contribution of Lactococcus lactis reducing properties to the downregulation of a major virulence regulator in Staphylococcus aureus, the agr system. Applied and Environmental Microbiology 80 (22), 7028-7035. https://doi.org/10.1128/AEM.02287-14

23. Novick, R.P. (2003): Autoinduction and signal transduction in the regulation of staphylococcal virulence. Molecular Microbiology 48, 1429-1449. https://doi.org/10.1046/j.1365-2958.2003.03526.x

24. Oh, S.K., Lee, N., Cho, Y.S., Shin, D.B., Choi, S.Y., Koo, M. (2007): Occurrence of toxigenic Staphylococcus aureus in ready-to-eat food in Korea. Journal of Food Protection 70, 1153-1158. https://doi.org/10.4315/0362-028X-70.5.1153
25. Piccinini, R., Cesaris, L., Dapra, V., Borromeo, V., Picozzi, C., Secchi, C., Zecconi A. (2009): The role of teat skin contamination in the epidemiology of Staphylococcus aureus intramammary infections. Journal of Dairy Research 76 (1), 36-41. https://doi.org/10.1017/S0022029908003671

26. Pragman, A.A., Schlievert, P.M. (2004): Virulence factor regulation in Staphylococcus aureus: The need for in vivo analyses. FEMS Immunology \& Medical Microbiology 42 (2), 147-154. https://doi.org/10.1016/j.femsim.2004.05.005

27. Saha, B., Harlan, D.M., Lee, K.P., June, C.H., Abe, R. (1996): Protection against lethal toxic shock by targeted disruption of the CD28 gene. The Journal of Experimental Medicine 183, 2675-2680. https://doi.org/10.1084/jem.183.6.2675

28. Schmitt, M., Schuler-Schmid, U., Schmidt-Lorenz, W. (1990): Temperature limits of growth, TNase and enterotoxin production of Staphylococcus aureus strains isolated from foods. International Journal of Food Microbiology 11 (1), 1-19. https://doi.org/10.1016/0168-1605(90)90036-5

29. Shiobara, N., Suzuki, Y., Aoki, H., Gotoh, A., Fujii, Y., Hamada, Y., Suzuki, S., Fukui, N. et al. (2007): Bacterial superantigens and $\mathrm{T}$ cell receptor beta-chain-bearing $\mathrm{T}$ cells in the immunopathogenesis of ulcerative colitis. Clinical \& Experimental Immunology 150, 13-21. https://doi.org/10.1111/j.1365-2249.2007.03443.x

30. Srinivasan, V., Sawant, A.A., Gillespie, B.E., Headrick, S.J., Ceasaris, L., Oliver, S.P. (2006): Prevalence of enterotoxin and toxic shock syndrome toxin genes in Staphylococcus aureus isolated from milk of cows with mastitis. Foodborne Pathogens and Disease 3 (3), 274-283. https://doi.org/10.1089/fpd.2006.3.274

31. Tamarapu, S., McKillip, J.L., Drake, M. (2001): Development of a multiplex polymerase chain reaction assay for detection and differentiation of Staphylococcus aureus in dairy products. Journal of Food Protection 64, 664-668. https://doi.org/10.4315/0362-028X-64.5.664

32. Thomas, D., Chou, S., Dauwalder, O. and Lina, G. (2007): Diversity in Staphylococcus aureus enterotoxins. Chemical Immunology and Allergy 93, 24-41. https://doi.org/10.1159/000100856

33. Vitale, M., Scatassa, M.L., Cardamone, C., Oliveri, G., Piraino, C., Alduina, R., Napoli, C. (2015): Staphylococcal food poisoning case and molecular analysis of toxin genes in Staphylococcus aureus strains isolated from food in Sicily, Italy. Foodborne Pathogens and Disease 12 (1), 21-23. https://doi.org/10.1089/fpd.2014.1760

34. Watanabe, H., Masaki, H., Asoh, N., Watanabe, K., Oishi, K., Kobayashi, S., Sato, A. and Nagatake, T. (2001): Enterocolitis caused by methicillin-resistant Staphylococcus aureus: molecular characterization of respiratory and digestive tract isolates. Microbiology and Immunology 45, 629-634. https://doi.org/10.1111/j.1348-0421.2001.tb01295.x

35. Zecconi, A., Cesaris, L., Liandris, E., Dapra, V., Piccinini, R. (2006): Role of several Staphylococcus aureus virulence factors on the inflammatory response in bovine mammary gland. Microbial Pathogenesis 40, 177-183. https://doi.org/10.1016/j.micpath.2006.01.001 